\title{
Konferencia Česká literatúra a film IV
}

\author{
Lenka Tkáč-Zabáková - Hana Guzmická (Nitra)
}

Dňa 19. 10. 2016 sa na Fakulte stredoeurópskych štúdií Univerzity Konštantína Filozofa v Nitre konal už 4. ročník medzinárodnej vedeckej konferencie s názvom Česká literatúra a film. Odbornými garantmi tohto každoročného podujatia sú profesori Miloš Zelenka a Tibor Žilka. Za nielen tradičnú, ale aj pozoruhodnú pokladáme spoluprácu s Velvvyslanectvom Českej republiky v Bratislave, ktoré sa podielalo i na finančnej podpore tohto projektu. Otvorenie konferencie sa uskutočnilo za účasti dekanky fakulty Žofie Bárcziovej, tá prejavila úprimnú radosṫ z úspechu konferencie, ktorá každoročne osloví množstvo odborníkov na danú problematiku nielen zo Slovenska, ale i zo zahraničia. Následne sa slova ujal tajomník Velvyslanectva Českej republiky v Bratislave Ondřej Pometlo, ktorý v príhovore vyslovil potešenie z toho, že konferencia každý rok dosahuje vysokú akademickú kvalitu a teší sa na d’alšiu spoluprácu. Hostí privítal aj riaditel Ústavu stredoeurópskych jazykov a kultúr Tibor Žilka, ktorý poukázal na dôležitost’ a význam špecifických podujatí, akým je aj toto stretnutie odborníkov z oblasti českej kultúry a umenia.

Ako prvý prednášal Petr Kučera zo Západočeskej univerzity v Plzni. Ústrednou postavou jeho príspevku bol český športový novinár, reportér a neskôr prozaik Ota Pavel, ktorého osud a životný príbeh poznačili aj jeho tvorbu. V sedemnástich rokoch ho otec prihlásil do KSČ a tento „píšuci reportér“ židovského pôvodu sa spolu s Hrabalom stal alternatívou k tomu, čo v Čechách v sedemdesiatych rokoch minulého storočia oficiálne vychádzalo. Jeho literárna tvorba bola zasadená do židovského kontextu a rád využíval rozpor prísnej vizuálnej tradície judaizmu a západného sveta, svojich hrdinov $\mathrm{s}$ často biografickými prvkami staval do pozície outsidera. Postavou niektorých diel bol jeho otec, pričom rád využíval prostriedky antiliterárnosti, ako napríklad gýč, sentiment a fantáziu.
Hostujúci vysokoškolský pedagóg Roman Shkilev z Kazaňskej federálnej univerzity sa vo svojej prezentácii venoval téme holokaustu a „Pražskej jari” v dielach židovských spisovatelov v českej literatúre. Vyzdvihol prínos tvorby Arnošta Lustiga, Ladislava Grosmana či Franza Kafku a význam ruskej židovskej komunity v Izraeli, ktorá zabezpečuje preklady diel týchto autorov do ruštiny. Zároveň zdôraznil význam migrácie stredoeurópskeho obyvatel'stva, vd’aka ktorému došlo $\mathrm{k}$ celkovému rozšíreniu stredoeurópskej židovskej literatúry v ruskom priestore.

$\mathrm{S}$ d’alším príspevkom vystúpil Petr Bubeníček z Masarykovej univerzity v Brne, ktorý analyzoval moderné adaptačné procesy a d’alšie aktuálne otázky z oblasti originality textu či model samotných adaptačných štúdií. Vyzdvihol význam publikácie Teória adaptácie od Lindy Hutcheon, ktorá sa venuje danej problematike nielen ako výsledku, ale aj procesu, presahujúc štúdiá intermediality.

Michaela Malíčková z Ústavu literárnej a umeleckej komunikácie Filozofickej fakulty UKF, ktorá sa vo svojom výskume dlhodobo venuje tematike sémantického preverovania upírskej postavy, predstavila románovú ságu českej autorky Jenny Nowak.

S prednáškou vystúpil i literárny kritik Alexej Mikulášek, ktorý v minulosti spolupracoval na vydaní slovníkovej príručky Literatura s hvězdou Davidovou. Jeho príspevok na konferencii bol zameraný na otázku stereotypov v tvorbe Martina Nezvala a ich využitia vo filmovej adaptácii jeho románu Jak ulovit miliardáre. Príspevok Radka Malého bol venovaný súčasnej českej literatúre pre deti a mládež a jej stvárneniu vo filme. Autor ponúkol náhlad na niekol'ko českých filmov určených detskému divákovi, ako napríklad Už zase skáču přes kaluže, Káta a krokodýl či Táto, sežeň štěně! Vychádzajúc z bohatej tradície českej tvorby pre spomínanú cielovú skupinu poukázal aj na zmenu terminológie - aj napriek zachovaniu inšpiračných zdrojov 
v klasických českých literárnych predlohách a iných aspektov, v nedávnej minulosti sa po vzore západnej produkcie aj v českom filmovom priemysle začalo presadzovat pomenovanie „rodinný film“.

$\mathrm{V}$ závere dopoludňajšieho bloku odznela prednáška Petra Žantovského z Fakulty žurnalistiky Karlovej Univerzity v Prahe, ktorý zmapoval českú literatúru ako inšpiračný zdroj českej kinematografie pred a po roku 1990. Neobišiel ani československú novú vlnu, ktorá je všeobecne považovaná za jedno z najvýznamnejších období nielen lokálnej kinematografie.

Po krátkej prestávke pokračoval poobedňajší blok prednášok v dvoch sekciách. Úvodná prednáška v jednej z nich patrila Tatiane Ďuricovej, internej doktorandke Karlovej univerzity v Prahe, ktorá sa vo svojom výskume venuje filmovým adaptáciám rozprávky Josefa Kajetána Tyla Strakonický dudák a ich komparácii. Prvá filmová adaptácia dudáka vznikla v roku 1937 v réžii Svatopluka Innemanna s názvom Švanda dudák. V roku 1955 uzrel svetlo sveta film režiséra Karla Steklého Strakonický dudák. Posledná adaptácia s názvom Hvězda padá vzhưru je z roku 1974. V diskusii nazval P. Kučera Tyla ,ikonickou postavou českosti“. Zaujímavá bola aj prednáška Petry Bad’ovej z Ústavu literárnej a umeleckej komunikácie FF UKF s názvom Semiotika podkrovia a pivnice s prioritným zameraním na filmy $N a$ půde aneb Kdo má dneska narozeniny? a Do pivnice. Predstavila model pivnice a podkrovia $\mathrm{v}$ hororoch a rozprávkach. Režisérom prvého z menovaných filmov je jeden z najoriginálnejších a najuznávanejších tvorcov v oblasti animovaného filmu Jiří Bárta. Druhý režíroval Jan Švankmajer. Tému Markéta Lazarová - Od Vančury k Vláčilovi analyzoval Martin Lukáš z olomouckej univerzity. Koncentroval sa na literárno-kritickú recepciu Markéty Lazarovej ako na objekt spoločenskej diskusie. Prednášajúci komparoval a analyzoval literárnu predlohu a film režiséra Františka Vláčila Markéta Lazarová, ktorý bol v roku 1998 v ankete filmových kritikov vyhlásený za najvýznamnejší film storočnej histórie českej kinematografie a zároveň najdrahším československým filmom šest'desiatych rokov. Dodnes je Markéta Lazarová fenoménom tak v literatúre, ako vo filmovom umení. Posledná prednáška patrila Janovi Jindrovi z Karlovej univerzity v Prahe. Prítomným priblížil adaptácie Jiráskovej Lucerny vo filmoch režiséra Karla Lamača, ktorého označil ako „vedúcu osobnost' tzv. zlatej éry medzivojnovej československej kinematografie“.

$\mathrm{V}$ úvode druhého popoludňajšieho bloku Nikola Danišová priblížila motív transfigurácie v básnickej rozprávke Františka Hrubína Kráska a zviera a jej filmovej adaptácie Panna a netvor natočenej českým režisérom slovenského pôvodu Jurajom Herzom. Jeho postava „zvierata“ má okrem atribútov tradične čiastočne ludskej, čiastočne animálnej postavy dominujúce negatívne až hororové duševné aj fyzické charakteristiky netvora v pravom slova zmysle. Ďalšia prednáška Lenky Tkáč-Zabákovej sa venovala analýze a hladaniu spoločných a rozdielnych znakov filmových adaptácií venujúcich sa téme operácie Antropoid. Autorka sa zamerala na pôvodnú Sequensovu snímku z roku 1964, ktorá mala názov Atentát, a modernému spracovaniu rovnakej udalosti, ktoré v roku 2016 vzniklo vdaka medzinárodnej koprodukcii pod vedením britského režiséra Seana Ellisa, Anthropoid. V poslednej prezentácii tejto sekcie sa Martin Kudláč, rovnako ako predchádzajúci autori príspevkov v tomto doktorandskom bloku pôsobiaci na UKF, venoval českej kinematografii prítomnosti a blízkej budúcnosti a rôznym podobám literárnych vplyvov na ňu. Vyzdvihol jedinečnost' súčasných postmoderných spracovaní historických a iných námetov, s dôrazom na vizuálnost' spracovaní a ich vysokú kvalitu, experimentátorstvo, narúšanie tradičných žánrových vzorcov a vznik hybridných formátov, ktoré sa stávajú neoddelitelnou súčastou modernej českej filmografie. Po odznení záverečného slova od pracovníka Ústavu stredoeurópskych jazykov a kultúr a zároveň organizačného garanta konferencie Česká literatúra a fim Štefana Timka bola jej oficiálna čast' ukončená. Diskusia o výnimočnosti príspevkov a celého podujatia ešte nejaký čas doznievala priestormi fakulty pod Zoborom. 
Mgr. Lenka Tkáč-Zabáková / lenka.tkaczabakova@ukf.sk

Mgr. Hana Guzmická / hana.guzmicka@ukf.sk

Ústav stredoeurópskych jazykov a kultúr

Fakulta stredoeurópskych štúdií, Univerzita Konštantína Filozofa v Nitre

Nitra, Slovenská republika 